\title{
PENENTUAN KOMBINASI KERNEL TERBAIK MENGGUNAKAN MEDIAN FILTER
}

\author{
Yudianingsih $^{1}$, Latifah Listyalina ${ }^{2}$ \\ Jurusan Teknik Elektro, Fakultas Sains \& Teknologi Universitas Respati Yogyakarta, ${ }^{1,2}$ \\ Jl. Laksda Adisucipto Km 6,3 Depok, Sleman, Yogyakarta 55281 Telp 0274489780 \\ E-mail :nadia_yudia@yahoo.co.id' ${ }^{l}$, listyalina@gmail.com ${ }^{2}$
}

\begin{abstract}
Many factors such as the use of low-quality lens, inappropriate image acquisition technique, and the uncertainty of environment condition affect digital image acquisition process. As a result, noisy image may be obtainedwhich is difficult to be recognized, processed, and analysed. The most occurred noise is salt and pepper which appears as white and black spots in image. This noise is usually removed or suppressed using median filter. However, improper size of median filter kernel may yield in poor result. This work aims to find the most suitable median filter kernel size combination using Breadth search, Depth Searchand Generate and Testmethods in order to obtain the best median filtering result. In this work, four median filter kernel sizes are used, i.e. $3 \times 3,5 \times 5,7 \times 7$, and $9 \times 9$. Filtering performance using each obtained combination is defined by measuring the Mean Square Error (MSE) of the filtered and unnoisy image (ground truth). Result shows that the best median filter kernel size combination is $\{3 \times 3\}$. This combination is obtained using Breadth Search Method with the MSE of 27.0308.
\end{abstract}

Keywords : Digital Image, Breadth search, Depth Search, Generate and Test, Kernel, Filter Median, Salt and Pepper.

\section{PENDAHULUAN}

Hampir semua citra yang dihasilkan oleh alat akuisisi citra memerlukan metode peningkatan kualitas untuk selanjutnya dilakukan komputasi lanjut seperti segmentasi, rekontruksi, dan lain sebagainya. Salah satu jenis derau yang paling sering terlihat adalah jenis salt and paper. Derau ini memiliki ciri seperti citra yang terkontaminasi titik - titik derau dengan warna putih (salt) atau hitam (pepper).

Saat ini banyak dilakukannya pengolahan citra khususnya metode untuk meningkatkan kualitas citra yang terkena derau salt and paper ini dan salah satu metodenya dapat menggunakan filter berbasis statistik yaitu filter median atau tapis median. Tapis median efektif digunakan untuk mengatasi derau salt and pepper. Prinsip kerja dari tapis median adalah menggunakan sliding neighborhood dengan dengan mengambil nilai tengah kernel tersebut. Kernel yang digunakan dalam penelitian ini adalah $3 \times 3$, $5 \times 5,7 \times 7$, dan $9 \times 9$ dengan asumsi ukuran kernel kecil tersebut dapat menghilangkan derau tanpa menghilangkan ciri citra aslinya.

Dalam proses penapisan citra ada bebarapa metode yang digunakan untuk memproses citra, diantaranya metode tapis median dua dimensi. Tapis median citra digital yang digunakan adalah tapis median dua dimensi dan multilevel tapis median. Operasi penapisan citra menggunakan ukuran matriks $3 \times 3,5 \times 5,7 \times 7$ dan $9 \times 9$. Jenis citra dengan ekstensi bmp berformat 24 bit dengan ukuran piksel $640 \times 480$. Citra tersebut kemudian ditampilkan ke dalam program lalu dilakukan proses penapisan citra, menampilkan histogram, timing run, serta Signal to Noise Ratio (SNR) dari citra filter. Dari hasil penelitian diperoleh bahwa jenis citra, ukuran citra, ukuran matriks, dan metode yang dipilih mempengaruhi proses penapisan citra. (Murinto, 2012).

Penelitian ini mengangkat suatu metode dalam penghilangan noise citra yaitu switching median filter yang digabung dengan sebuah metode deteksi noise yang disebut Boundary Discriminative Noise 
Detection (BDND). Citra yang mengalami proses editing ataupun kompresi biasanya akan terkontaminasi noise yang akan mengurangi kualitas citra. Beberapa teknik filtering telah diperkenalkan untuk penghilangan noise citra. Hasil uji coba pada citra grayscale dan warna dengan range noise density antara 10\%-90\% menunjukkan bahwa switching median filter yang digabung dengan algoritma BDND mempunyai kinerja yang sangat bagus dalam mengembalikan detil citra dalam range noise density antara 10\% -70\% (Saikhu, 2009).

Dari penelitian yang telah dilakukan, terbukti bahwa penggunaan median filter dalam mengeliminasi salt and pepper. Penggunaan median filter itu sendiri juga mempunyai suatu kelemahan yaitu gambar yang sudah diproses akan tampak sedikit blur atau kabur. Dari segi kecepatan proses, median filter membutuhkan waktu yang digunakan untuk pengurutan data. Dari hasil penelitian juga didapat bahwa waktu proses masing-masing filter dipengaruhi oleh besarnya ukuran gambar yang diproses. Semakin besar ukuran gambar yang diproses, semakin lama juga waktu prosesnya. Berapapun jumlah noise yang ada pada gambar, waktu prosesnya akan tetap sama, selama ukuran gambar yang diproses adalah sama. Untuk menyempurnakan kelemahan yang ada pada Metode Median Filter perlu dilakukan perbaikan atau kombinasi-kombinasi, misalnya dengan pemberian bobot pada pixel (Sulistyo, 2009).

Di dalam penelitian ini dirancang sebuah algoritma untuk meningkatkan kualitas citra digital derau salt and pepper berbasis pada Blind Search dan Heuristic Search. Metode khusus yang digunakan pada penelitian ini adalah Breadth Search, Depth Search, dan Generate and Test. Prinsip kerja metode ini adalah untuk mencari kernel yang terbaik, yaitu kombinasi kernel menggunakan metode - metode tersebut untuk mengurangi derau semaksimal mungkin.

\section{TINJAUAN PUSTAKA}

\subsection{Citra}

Citra merupakan kumpulan elemen gambar yang secara keseluruhan merekam suatu adegan / scene melalui media indra visual. Citra dapat dideskripsikan sebagai data 2 dimensi dalam bentuk matriks. Citra digital adalah citra 2 dimensi yang dapat direpresentasikan dengan sebuah fungsi intensitas cahaya dimana $x$ dan $y$ menyatakan koordinat spasial. Elemen terkecil dari sebuah citra digital disebut dengan image element, picture element, pel atau pixels. (Ahmad, 2005).

Citra digital direpresentasikan dalam bentuk matriks $\mathrm{H} \times \mathrm{W}$ ( $\mathrm{H}=$ tinggi, $\mathrm{W}=$ lebar). Bila citra memiliki 256 derajad keabuan, maka nilai setiap elemen matriks adalah bilangan bulat dalam selang 0 sampai 255. Pusat koordinat citra digital terletak pada sudut kiri atas sedangkan pada koordinat kartesius terletak pada sudut kiri bawah (R. Munir, 2004).

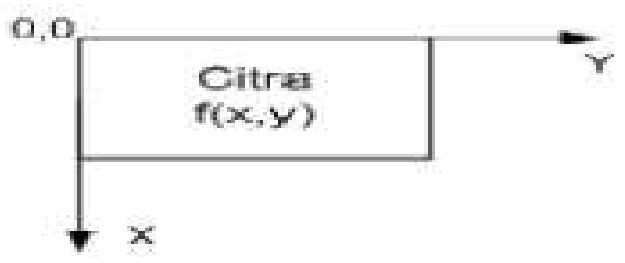

Gambar 1. Koordinat Citra (Munir, 2004).

Citra berwarna terdiri dari tiga layer matriks, yaitu $R$-layer, $G$-layer, dan B-layer. Grayscale merupakan operasi yang digunakan untuk mengubah tiga layar $(\mathrm{R}, \mathrm{G}$, dan B) menjadi satu layer matrik grayscale dan hasilnya adalah citra grayscale. Dalam citra greyscale tidak ada lagi citra berwarna, yang ada adalah derajat keabuan (Listyalina, 2016). Untuk mengubah citra berwarna yang mempunyai nilai matrik masing - masing $\mathrm{r}$, $\mathrm{g}$, dan b menjadi citra grayscale dengan nilai $\mathrm{s}$, maka konversi dapat dilakukan dengan mengambil rata - rata nilai $r$, g, dan $b$ sehingga dapat dituliskan menjadi :

$s=\frac{T+g+b}{3}$ 


\subsection{Pengolahan Citra}

Meskipun citra sebuah informasi kaya informasi, namun seringkali citra mengalami penurunan mutu (degradasi), misalnya mengandung cacat atau derau (noise), warnanya terlalu kontras, kurang tajam, kabur (blurring), dan sebagainya. Agar citra yang mengalami gangguan mudah di interpretasi (baik oleh manusia ataupun mesin), maka citra tersebut perlu dimanipulasi menjadi citra lain yang kualitasnya lebih baik (pengolahan citra). Pengolahan citra adalah pemrosesan citra, khusunya dengan menggunakan komputer, menjadi citra yang kualitasnya lebih baik (Bourne, 2010).

Pengolahan citra digital adalah suatu proses untuk memperbaiki kualitas citra atau memanipulasi suatu citra agar mudah diintepretasi oleh manusia. Pada proses ini output dari proses tetap berupa citra namun dengan kualitas yang lebih baik dari citra yang sebelumnya. (Karimah, 2012).



Gambar 2. Proses Pengolahan Citra (Karimah, 2012).

Metode median filter merupakan filter non - linear, yang berfungsi untuk menghaluskan dan mengurangi noise atau gangguan pada citra. Filter median sangat populer dalam pengolahan citra. Filter ini dapat dipakai untuk menghilangkan derau bintik - bintik. Nilai yang lebih baik digunakan untuk suatu piksel ditentukan oleh nilai median dari setiap piksel dan kedelapan piksel tetangga pada 8-ketetanggaan (Pratt, 2007).

Sebagai contoh jika diketahui suatu matrik berdimensi $3 \times 3$ yang berisi piksel utama dan piksel-piksel di sekitarnya.

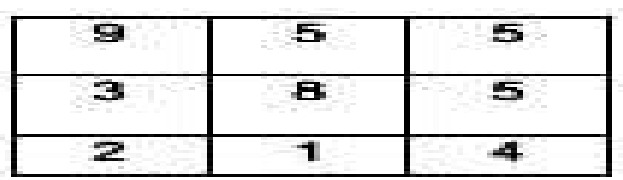

dahulu dan dımasukkan dalam sebuah matrik yang berukuran $1 \times(3 \times 3)$ atau $1 \times 9$ yaitu sebagai berikut.

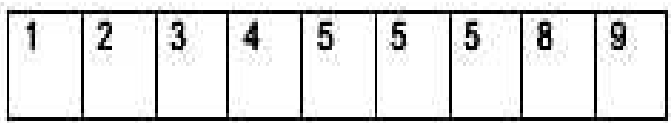

Dari pernyataan di atas, dapat dicari nilai piksel yang baru dengan menggunakan perhitungan median. Maka nilai mediannya ialah 5. Nilai 5 ini akan menggantikan nilai 8 sehingga piksel utamanya akan memiliki intensitas warna yang berbeda dengan sebelumnya (Putra, 2010).

\subsection{Mean Square Error}

Mean Square Error (MSE) digunakan sebagai parameter performa objektif dalam mengukur kualitas citra. MSE merupakan nilai yang menyatakan rata - rata kuadrat error, di mana dalam hal ini error menyatakan selisih antara citra asli dengan citra terderau maupun citra hasil penapisan. Kriteria performa yang baik dengan menggunakan parameter MSE adalah nilai MSE yang kecil. Artinya, semakin kecil nilai MSE dari citra hasil penapisan, maka citra tersebut semakin baik (Gonzales, 2004). Mean Square Error dapat dihitung dengan meggunakan rumus yaitu sebagai berikut.

$$
M S F=\frac{1}{M \nu} \sum_{x-1}^{M} \sum_{y-1}^{N}\left(S_{x y}-C_{x y}\right)^{2}
$$

Dimana $\mathrm{x}$ dan $\mathrm{y}$ adalah koordinat dari gambar, $\mathrm{M}$ dan $\mathrm{N}$ adalah dimensi dari gambar, $\mathrm{S}_{\mathrm{xy}}$ menyatakan stego-image, dan $\mathrm{C}_{\mathrm{xy}}$ menyatakan cover-image (Kusumadewi, 2012).

\subsection{Model Sistem Real}

Sistem pencarian kernel terbaik dilakukan dengan menggunakan tiga model yaitu Breadth Search, Depth Search, dan Generate And Test. Breadth Search dan Depth Search adalah metode dari Blind Search. Jika Breadth Search dimulai dari atas kemudian pencarian dilakukan ke samping terlebih dahulu maka Depth Search dilakukan dari atas hingga ke paling bawah dahulu 
kemudian baru bergeser ke sisi kanan. Masing - masing model di tunjukkan seperti pada gambar 3 berikut.

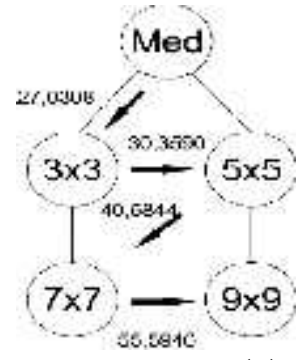

(a)

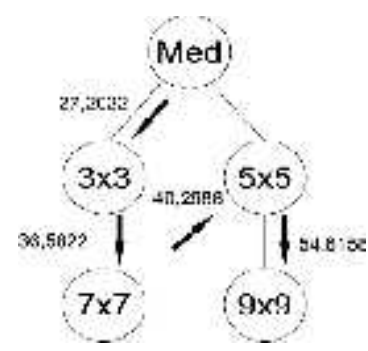

(b)
Gambar 3. Breadth Search (a) dan Depth Search (b) (Novriyanto, 2013).

Generate and Test adalah metode pencarian kernel secara komprehensif dengan mempertimbangkan kombinasi dari jumlah kernel tersebut. Dari segi tingkat kerumitan, Generate And Test memiliki kerumitan yang lebih jika dibandingkan dengan Metode Blind Search. Namun secara hasil, metode ini mempunya performa yang lebih baik (Novriyanto, 2013). Model system real yang dibangun dari permasalahan ini dapat dilihat pada Gambar 4 sebagai berikut.

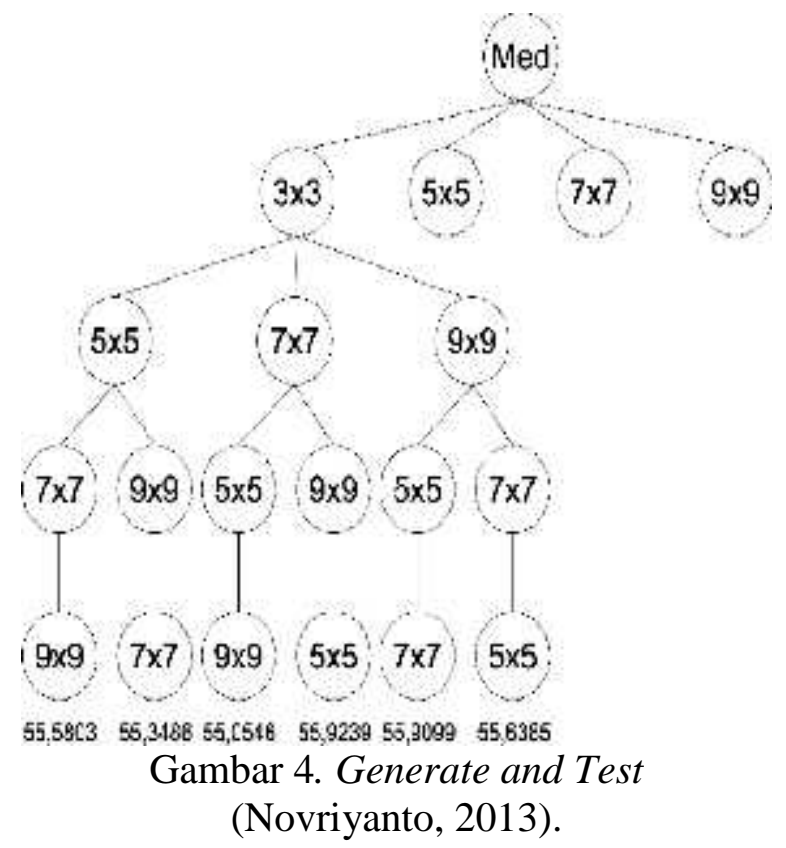

\section{METODE PENELITIAN}

Adapun tahapan dalam penelitian ini diilustrasikan pada gambar 5 di bawah ini, yaitu sebagai berikut.

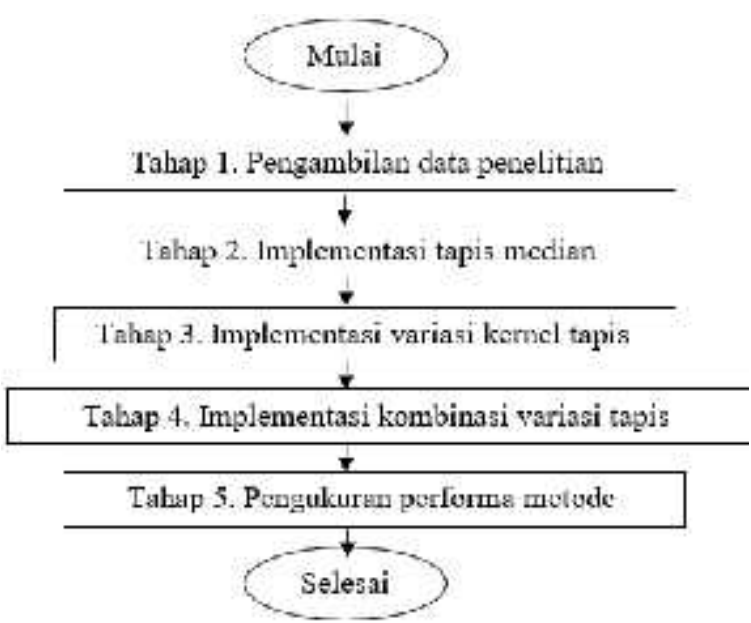

Gambar 5. Tahapan Penelitian.

\subsection{Tahap 1. Pengambilan Data Penelitian}

Pengambilan sampel penelitian berupa citra salt and pepper. Citra yang digunakan dalam penelitian ini diambil langsung dari Perangkat Lunak Matlab di mana citra tersebut bernama citra 'rice'. Citra yang diambil dari Matlab tersebut belum merupakan citra yang mempunyai derau. Sesuai dengan tujuan pada penelitian ini, yaitu melakukan pengukuran hasil kualitas menggunakan Mean Square Error (MSE) dengan membandingkan citra asli dengan citra hasil, maka pada penelitian ini terdapat dua buah jenis citra. Citra pertama yaitu citra 'rice' dan citra kedua yaitu citra 'rice' setelah diberikan derau jenis salt and pepper. Sehingga pada hasil penelitian ini, nilai performa diperoleh dengan membandingkan citra asli dan citra setelah diberikan derau dan telah ditapis menggunakan kombinasi median filter menurut model sistem real yang digunakan.

\subsection{Tahap 2. Implementasi Tapis Median}

Noise merupakan gangguan yang disebabkan oleh menyimpangnya data digital yang diterima oleh alat penerima data gambar yang mana dapat mengganggu kualitas citra. Derau dapat disebabkan oleh gangguan fisis (optik) pada alat penangkap citra misalnya kotoran debu yang menempel 
pada lensa foto maupun akibat proses pengolahan yang tidak sesuai. Ada tiga jenis noise yaitu gaussian noise, speckle noise, dan salt and pepper noise. Gaussian noise merupakan model noise yang mengikuti distribusi normal standard dengan rata - rata nol dan standard deviasi 1. Efek dari gaussian noise ini pada gambar adalah munculnya titik - titik berwarna yang jumlahnya sama dengan persentase noise. Noise speckle merupakan model noise yang memberikan warna hitam pada titik yang terkena noise. Noise salt and pepper adalah bentuk noise yang biasanya terlihat titik titik hitam dan putih pada citra seperti tebaran garam dan merica. Noise salt and pepper disebabkan karena terjadinya error bit dalam pengiriman data, pixel - pixel yang tidak berfungsi dan kerusakan pada lokasi memori.

Pengolahan citra untuk menghilangkan derau citra. Derau citra yang dipilih ialah salt and pepper. Derau tersebut diminimalisasi pada langkah ini dengan menggunakan tapis median.

\subsection{Tahap 3. Implementasi Variasi Kernel Tapis Median}

Pada tapis median, terdapat beberapa ukuran kernel yang dapat digunakan. Ukuran tersebut berbentuk persegi di mana mempunyai ukuran sisi yang sama besar. Beberapa contoh ukuran kernel yaitu 3, 5, 7, dan 9. Variasi ukuran kernel pada filter median untuk meminimalisasi derau citra.

\subsection{Tahap 4. Implementasi Kombinasi Variasi Kernel Tapis Median}

Dari beberapa variasi ukuran kernel yang digunakan, dilakukan kombinasi dari ukuran - ukuran kernel yang digunakan.Urutan kombinasi tersebut dilakukan berdasar model sistem real Breadth Search, Depth Search, dan Generate and Test yaitu sesuai pada Gambar 6 berikut.

Hasil dari peneltian ini adalah citra hasil penapisantapis median dengan masingmasing urutan kombinasi kernel yang dihasilkan olehmodel sistem real Breadth
Search, Depth Search, dan Generate and Test.

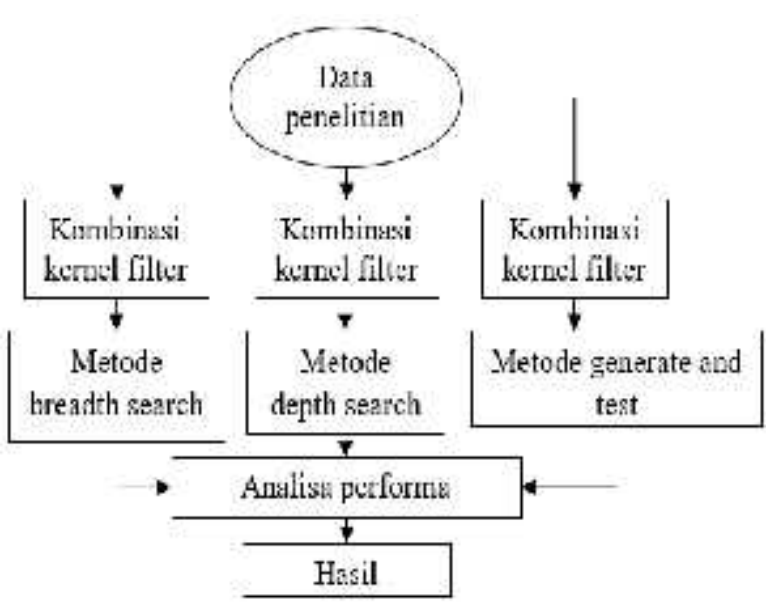

Gambar 6. Urutan Kombinasi Kernel

Median Filter.

\subsection{Tahap 5. Pengukuran Performa Metode}

Untuk mendapatkan hasil penelitian yang dapat dipertanggung jawabkan, maka analisis hasil penelitian ini akan dilaksanakan dengan melakukan perhitungan Mean Square Error (MSE) yang merupakan parameter performa obyektif dalam mengukur kualitas citra. Citra hasil kombinasi kernel pada tapis median dengan menggunakan model sistem realBreadth Search, Depth Search, dan Generate and Test dibandingkan dan diukur performanya untuk dipilih citra yang terbaik dengan derau yang minimal.

\section{HASIL DAN PEMBAHASAN}

Pengambilan sampel data citra asli yang telah diberi derau salt and pepper. Pengambilan sampel penelitian berupa citra salt and pepper. Citra yang digunakan dalam penelitian ini diambil langsung dari Perangkat Lunak Matlab di mana citra tersebut bernama citra 'rice'. Citra yang diambil dari Matlab tersebut belum merupakan citra yang mempunyai derau. Data citra ini dapat dilihat pada Gambar 7 gambar 7. 


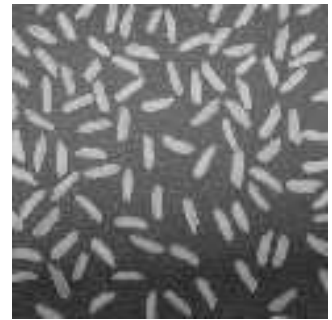

Gambar 7. Citra 'Rice'.

Sesuai dengan tujuan pada penelitian ini, yaitu melakukan pengukuran hasil kualitas menggunakan Mean Square Error (MSE) dengan membandingkan citra asli dengan citra hasil, maka pada penelitian ini terdapat dua buah jenis citra. Citra pertama yaitu citra 'rice' dan citra kedua yaitu citra 'rice' setelah diberikan derau jenis salt and pepper. Data citra ini dapat dilihat pada gambar 8 .

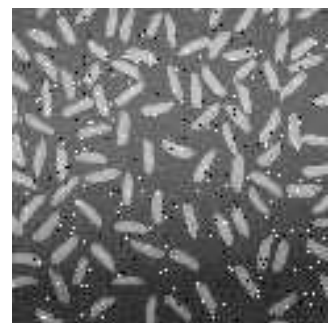

Gambar 8. Citra 'Rice’ Setelah

Diberikan Derau Jenis Salt and Pepper.

Pada hasil penelitian ini, nilai performa diperoleh dengan membandingkan citra asli dan citra setelah diberikan derau dan telah ditapis menggunakan kombinasi median filter menurut model sistem realyang digunakan. Di bawah ini merupakan contoh penggunaan tapis median dengan ukuran kernel 3.

\begin{tabular}{|l|l|l|l|l|}
\hline 43 & 38 & 25 & 45 & 38 \\
\hline 57 & 45 & 98 & 33 & 45 \\
\hline 55 & 54 & 57 & 45 & 43 \\
\hline 74 & 58 & 67 & 62 & 58 \\
\hline
\end{tabular}

\begin{tabular}{|l|l|l|l|l|}
\hline 43 & 38 & 25 & 45 & 38 \\
\hline 57 & 45 & 45 & 33 & 46 \\
\hline 65 & 54 & 57 & 45 & 43 \\
\hline 74 & 58 & 67 & 62 & 58 \\
\hline
\end{tabular}

Gambar 9. Penerapan Tapis Median dengan Kernel berukuran $3 \times 3$.
Contoh citra sebelum (a) dan sesudah dilakukan tapis median (b) yaitu sebagai berikut.

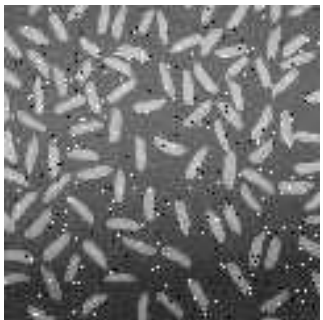

(a)

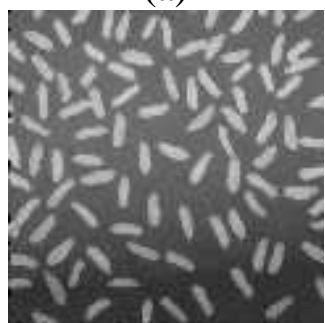

(b)
Gambar 10. Citra Sebelum Dilakukan

Tapis Median (a) Dan Citra Setelah

Dilakukan Tapis Median (b).

\subsection{Sistem Real Breadth Search}

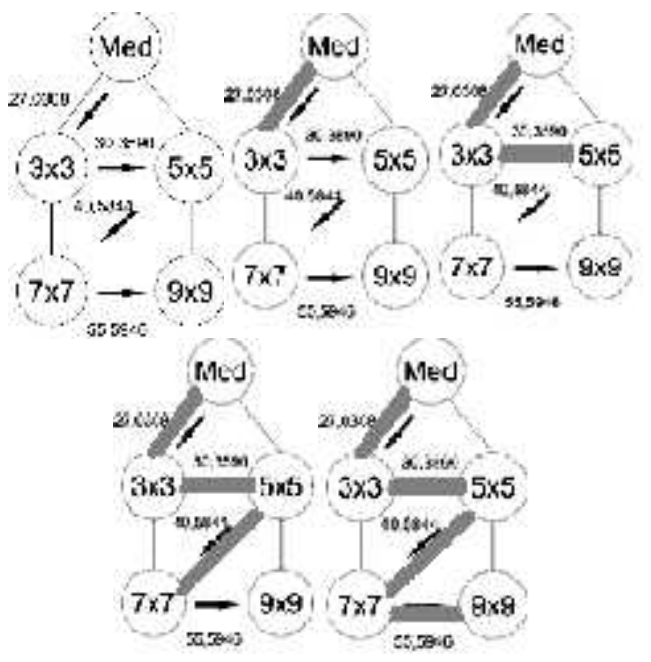

Gambar 11. Urutan Model Sistem Real Breadth Search.

Dari skema model sistem Real Breadth Search di atas, diperoleh bahwa urutan model ini dimulai dengan kernel tapis median yang berukuran $3 \times 3,5 \times 5,7 \times 7$, dan $9 \times 9$. Setiap langkah pada sistem real ini dihitung mulai MSE di mana hasil performa tersebut yang nantinya dibandingkan dengan 
model lainnya dan akan diperoleh model dengan performa terbaik.

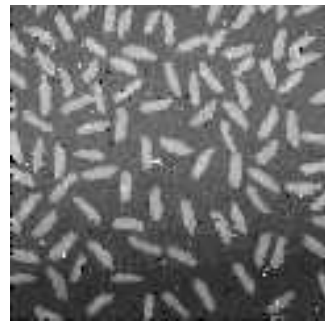

(a)

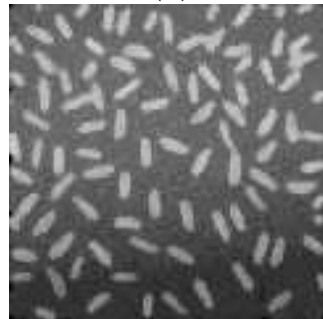

(c)

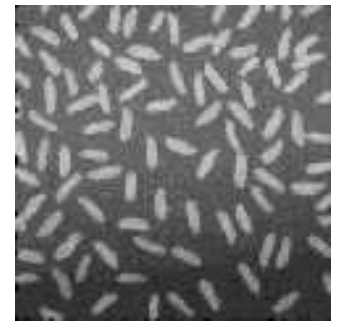

(b)

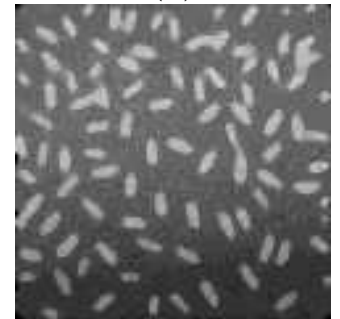

(d)
Gambar 12. Hasil Citra Model Sistem Real Breadth Search Kernel (a) $(3 \times 3)$ (b) $(3 \times 3,5 \times 5)(\mathrm{c})(3 \times 3,5 \times 5,7 \times 7)$ (d) $(3 \times 3,5 \times 5,7 \times 7,9 \times 9)$.

Pada sistem Real Breadth Search ini, diperoleh nilai MSE untuk setiap langkah yang berbeda-beda. Nilai MSE yang diperoleh dapat dilihat pada tabel 1 .

Tabel 1. Performa Citra Model Sistem Real Breadth Search.

\begin{tabular}{|l|c|c|c|c|}
\hline & & & & \\
Kernel & $(3 \times 3)$ & $(3 \times 3)(5 \times 5)$ & $\begin{array}{c}(3 \times 3)(5 \times 5) \\
(7 \times 7)\end{array}$ & $\begin{array}{c}(3 \times 3)(5 \times 5) \\
(7 \times 7)(9 \times 9)\end{array}$ \\
\hline MSE & 27,0308 & 30,3590 & 40,5844 & 55,5946 \\
\hline
\end{tabular}

Dari pengujian tapis median berdasarkan model pencarian kernel Real Breadth Search, sesuai tabel 1, nilai MSE minimal yang diperoleh adalah sebesar 27,0308.

\subsection{Sistem Real Depth Search}

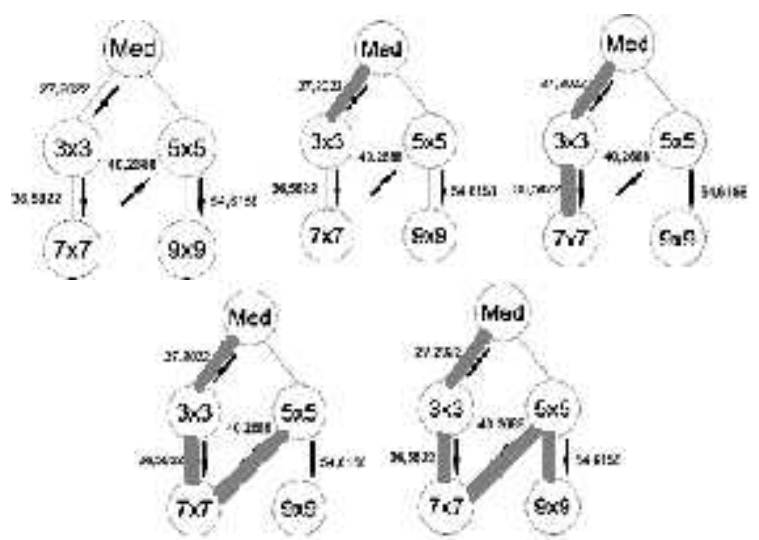

Gambar 13. Urutan Model Sistem Real Depth Search.

Dari skema model sistem Real Depth Search di atas, diperoleh bahwa urutan model ini dimulai dengan kernel tapis median yang berukuran $3 \times 3,7 \times 7,5 \times 5$, dan $9 \times 9$. Setiap langkah pada sistem real ini dihitung nulai MSE di mana hasil performa tersebut yang nantinya dibandingkan dengan model lainnya dan akan diperoleh model dengan performa terbaik.

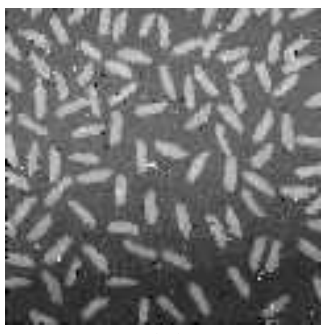

(a)

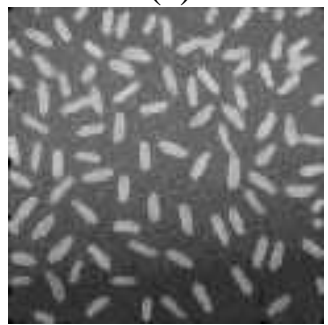

(c)

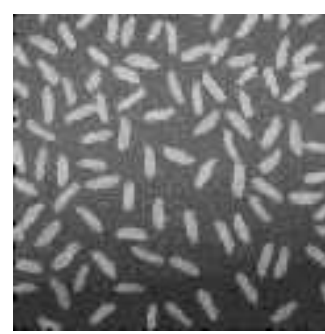

(b)

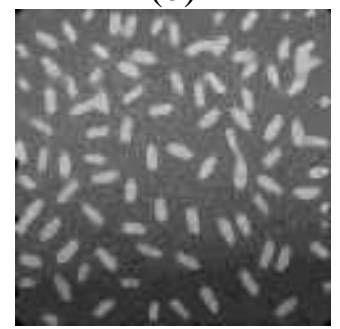

(d)
Gambar 14. Hasil Citra Model Sistem Real Depth Search Kernel

(a) $(3 \times 3)$ (b) $(3 \times 3,5 \times 5)($ c) $(3 \times 3,5 \times 5,7 \times 7)$ (d) $(3 \times 3,5 \times 5,7 \times 7,9 \times 9)$.

Pada sistem real ini, diperoleh nilai MSE untuk setiap langkah yang berbeda - beda. 
Tabel 2. Performa Citra Model Sistem Real Depth Search.

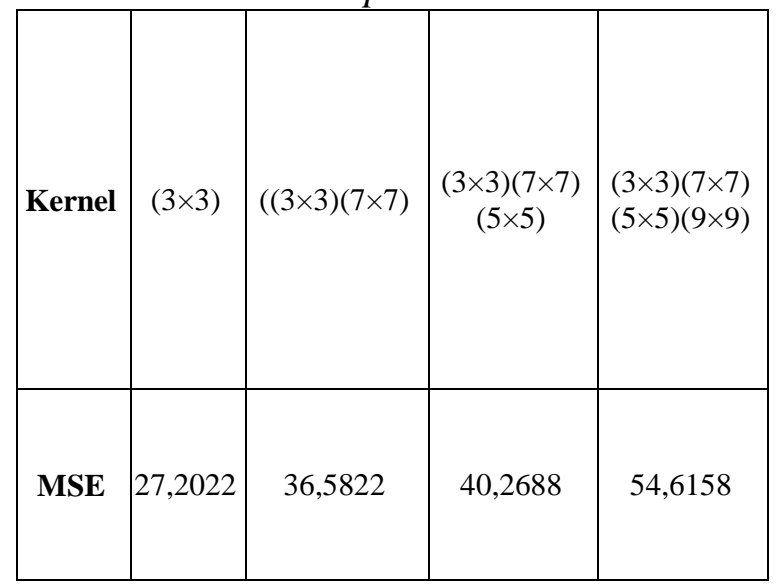

Dari pengujian tapis median berdasarkan model pencarian kernel Real Depth Search, sesuai tabel 2, nilai MSE minimal yang diperoleh adalah sebesar 27,2022.

\subsection{Sistem Real Generate and Test}

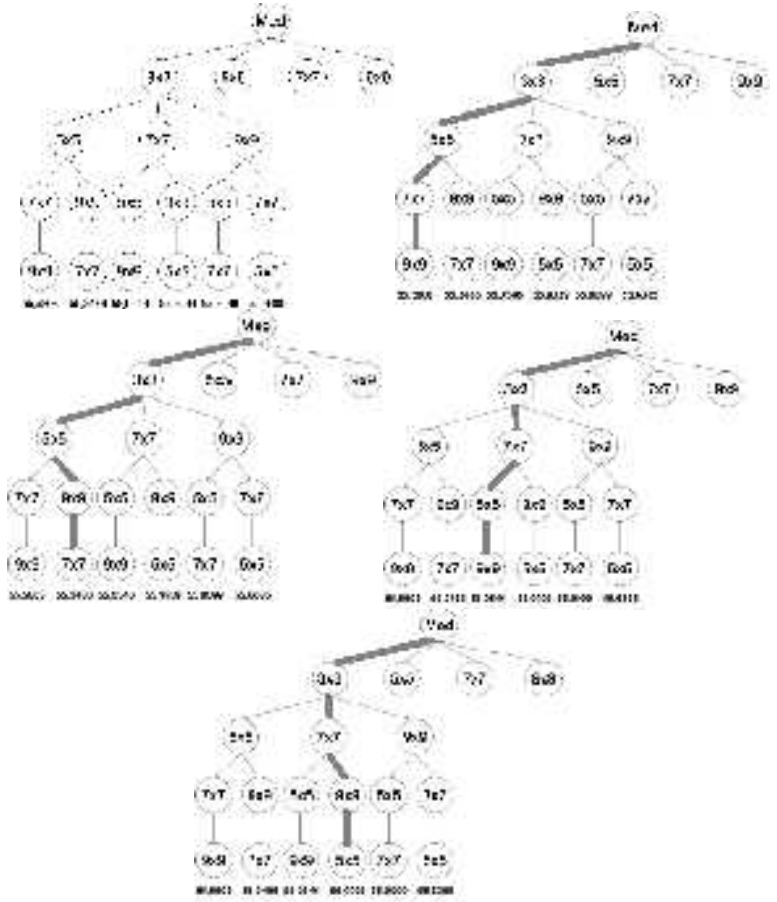

Gambar 15. Urutan Model Sistem Real Generate and Test.

Dari skema model sistem Real Generate and Test search di atas, diperoleh bahwa urutan model ini dimulai dengan kernel tapis median yang berukuran yaitu sebagai berikut.
a. Kernel $(3 \times 3)(5 \times 5)(7 \times 7)(9 \times 9)$.
b. Kernel $(3 \times 3)(5 \times 5)(9 \times 9)(7 \times 7)$.
c. Kernel $(3 \times 3)(7 \times 7)(5 \times 5)(9 \times 9)$.
d. Kernel $(3 \times 3)(7 \times 7)(9 \times 9)(5 \times 5)$.
e. Kernel $(3 \times 3)(9 \times 9)(5 \times 5)(7 \times 7)$.
f. Kernel $(3 \times 3)(9 \times 9)(7 \times 7)(5 \times 5)$.

Setiap langkah pada sistem real ini dihitung mulai MSE di mana hasil performa tersebut yang nantinya dibandingkan denganmodel lainnya dan akan diperoleh model dengan performa terbaik.

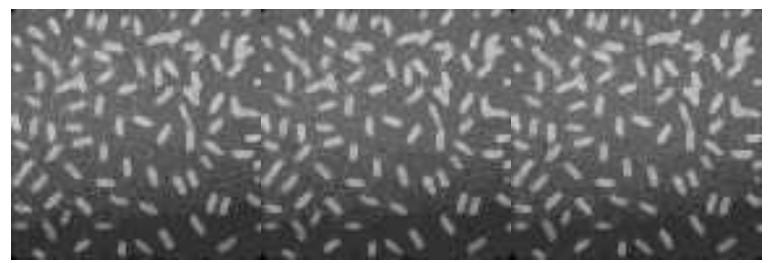

(a)

(b)

(c)

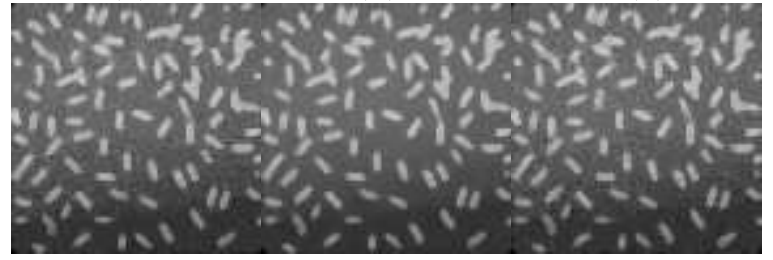

(d)

(e)

(f)

Gambar 16. Model Sistem Real Generate and Test.

a. Kernel $(3 \times 3)(5 \times 5)(7 \times 7)(9 \times 9)$.

b. Kernel $(3 \times 3)(5 \times 5)(9 \times 9)(7 \times 7)$.

c. Kernel $(3 \times 3)(7 \times 7)(5 \times 5)(9 \times 9)$.

d. Kernel $(3 \times 3)(7 \times 7)(9 \times 9)(5 \times 5)$.

e. Kernel $(3 \times 3)(9 \times 9)(5 \times 5)(7 \times 7)$.

f. Kernel $(3 \times 3)(9 \times 9)(7 \times 7)(5 \times 5)$.

Pada sistem real ini, diperoleh nilai MSE untuk setiap langkah yang berbeda-beda seperti pada tabel 3 .

Tabel 3. Performa Citra Model Sistem Real Generate and Test.

\begin{tabular}{|c|c|}
\hline Kernel & MSE \\
\hline$(3 \times 3)(5 \times 5)(7 \times 7)(9 \times 9)$ & 55,5803 \\
\hline$(3 \times 3)(5 \times 5)(9 \times 9)(7 \times 7)$ & 55,3486 \\
\hline$(3 \times 3)(7 \times 7)(5 \times 5)(9 \times 9)$ & 55,0546 \\
\hline$(3 \times 3)(7 \times 7)(9 \times 9)(5 \times 5)$ & 52,9239 \\
\hline$(3 \times 3)(9 \times 9)(5 \times 5)(7 \times 7)$ & 55,9099 \\
\hline$(3 \times 3)(9 \times 9)(7 \times 7)(5 \times 5)$. & 55,6385 \\
\hline
\end{tabular}


Dari pengujian tapis median berdasarkan model pencarian kernel Generate and Test, sesuai tabel 3 Tabel 3diperoleh nilai MSE minimal yang diperoleh adalah sebesar 55.3486 .

\section{KESIMPULAN}

Penelitian ini menggunakan data citra asli yang telah diberi derau salt and pepper didapatkan hasil MSE yang bervariasi dengan tiga metode yang berbeda. Nilai MSE pada masing-masing metode dapat ditunjukkan dengan tabel 4 Tabel 4 berikut.

Tabel 4. Perbandingan Nilai MSE Ketiga Metode.

\begin{tabular}{|c|c|}
\hline Metode & Mean Squre Error \\
\hline Breadth search & 27,0308 \\
\hline Depth Search & 27,2022 \\
\hline Generate and Test & 55.3486 \\
\hline
\end{tabular}

Metode Depth Search menghasilkan nilai MSE yang tidak jauh berbeda dengan Breadth Search. Dimana secara kasat mata gambar yang dihasilkan tidak dapat dibedakan. Output yang dihasilkan dari metode Depth Search maupun breadth search ini sudah cukup baik.

Dari hasil pengujian tersebut didapatkan nilai MSE terkecil pada metode Breadth Search yaitu 27,0308. Dengan waktu pengujian yang singkat yakni berhenti pada urutan pertama, maka metode breadth search ini adalah metode yang paling baik untuk pencarian kernel median filter. Sedangkan nilai MSE pada metode Depth Search terpaut tidak jauh yakni 27,2022 dan yang terakhir adalah metode generate and test memiliki nilai MSE terkecil sebesar 55.3486. Maka kernel yang paling baik diterapkan adalah ukuran $3 \times 3$ karena memiliki nilai MSE terkecil.

\section{Ucapan Terima Kasih}

Penulis mengucapkan terima kasih kepada Universitas Respati Yogyakarta yang telah memberi dukungan finansial terhadap penelitian ini. Terima kasih kami sampaikan pula kepada Dr. Yeny Sulistyowati, SKM, M.Si.Med selaku kepala P3M, Sri Hasta Mulyani, S.Kom, M.Kom selaku Dekan Fakultas Sains \& Teknologi, dan segenap rekan sejawat di Universitas Respati Yogyakarta yang telah membantu dalam proses penyelesaian penelitian ini.

\section{DAFTAR PUSTAKA}

Ahmad, Usman. Pengolahan Citra Digital \& Teknik Pemrogramannya. Penerbit Graha Ilmu : Yogyakarta, 2005.

Bourne, R. Fundamentals of Digital Imaging in Medicine. Springer-Verlag London Limited, 2010.

Gonzales, R.C.; Woods, R.E; Eddins, S.L. .Digital Image Processing Using MATLAB. Pearson LPE, 2004.

Karimah, Fatimatul. Implementasi Learning Vector Quantization (LVQ) Sebagai Alat Bantu Identifikasi Kelainan Jantung Melalui Citra Electro cardiogram. Surabaya. Universitas Airlangga, 2012.

Kusumadewi, Sri. Membangun Jaringan Syaraf Tiruan Menggunakan Matlab \& Excel Link. Penerbit Graha Ilmu: Yogyakarta, 2004.

Listyalina, Latifah. Automated Detection of Optic Disc and Centre of Macula to Facilitate The Diagnosis of Retinal Related Diseases. Yogyakarta. Universitas Gadjah Mada, 2016.

Munir, R, Pengolahan Citra Digital, Penerbit Informatika Bandung. Bandung, 2004.

Murinto. Analisis Perbandingan Metode 2D Median Filter dan Multi Level Median Filter pada Proses Perbaikan Citra Digital. Jurnal Informatika Yogyakarta, 2012.

Novriyanto. Penerapan Algoritma Back tracking Berbasis Blind Search untuk Menentukan Penjadwalan Mengajar. Seminar Nasional 
Aplikasi Teknologi Informasi (SNATI). Yogyakarta, 2013.

Pratt, William K. Digital Image Processing. John Wiley and Sons, Hoboken, New Jersey, 2007.

Putra, Darma. Pengolahan Citra Digital. Penerbit Andi: Yogyakarta, 2010.

Saikhu, Ahmad, dkk. Perbaikan Citra BerDerau Menggunakan Switching Median Filter Dan Boundary Discriminative Derau Detection. Seminar Nasional Aplikasi Teknologi Informasi 2009 (SNATI 2009). Yogyakarta, 2009.

Sulistyo, Wiwin, dkk. Analisis Penerapan Metode Median Filter Untuk Mengurangi Derau Pada Citra Digital. Konferensi Nasional Sistem dan Informatika. Bali, 2009. 